\title{
SWAT Modeling of Nitrogen Dynamics Considering Atmospheric Deposition and Nitrogen Fixation in a Watershed Scale
}

\author{
Chung-Gil Jung, Seong-Joon Kim \\ Department of Civil, Environmental and Plant Engineering, Konkuk University, Seoul, South Korea \\ Email:kimsj@konkuk.ac.kr
}

How to cite this paper: Jung, C.-G. and Kim, S.-J. (2017) SWAT Modeling of Nitrogen Dynamics Considering Atmospheric Deposition and Nitrogen Fixation in a Watershed Scale. Agricultural Sciences, 8, 326340.

https://doi.org/10.4236/as.2017.84024

Received: March 15, 2017

Accepted: April 27, 2017

Published: April 30, 2017

Copyright () 2017 by authors and Scientific Research Publishing Inc. This work is licensed under the Creative Commons Attribution International License (CC BY 4.0)

http://creativecommons.org/licenses/by/4.0/

\begin{abstract}
The Soil and Water Assessment Tool (SWAT) nitrogen (N) water quality model considers the artificial inputs associated with human activities, including point and nonpoint source pollution loads. Although SWAT has the ability to simulate atmospheric $\mathrm{N}$ deposition and fixation, they were not considered in the modeling research. $\mathrm{N}$ deposition from the air is an important and considerable pathway for the input of $\mathrm{N}$ species into watersheds and water bodies, causing soil and water body acidification and the leaching of $\mathrm{N}$ into surface and groundwater, resulting in eutrophication and degraded water quality. The goal of this study is to assess the effects of atmospheric and agricultural $\mathrm{N}$ loads on stream water quality at the watershed scale. For a 6642 $\mathrm{km}^{2}$ Chungju dam watershed, SWAT was calibrated for 4 years (2003-2006) and validated for another 4 years (2007-2010) using daily anthropogenic N data (sewage discharge pollutants and fertilizer) and monthly measured atmospheric deposition data for $\mathrm{NO}_{3}^{-}, \mathrm{NH}_{4}^{+}$, and dissolved organic $\mathrm{N}$ (DON). At the watershed outlet, the Nash-Sutcliffe (1970) efficiency (NSE) of daily streamflow during the validation period was 0.74 . The coefficient of determination $\left(\mathrm{R}^{2}\right)$ of total $\mathrm{N}$ was 0.69 considering atmospheric deposition, whereas it was 0.33 when removing the deposition effect. The results of this study demonstrate the potential for using the $\mathrm{N}$ dynamics between the atmosphere and land for SWAT assessments of nonpoint source pollution and for modeling stream water quality.
\end{abstract}

\section{Keywords}

SWAT, Anthropogenic Nitrogen, Atmosphere Deposition, Fixation, Fertilizer, Manure, Sewage Discharge Nitrogen

\section{Introduction}

Human activities, such as agricultural cultivation and fossil fuel combustion, 
have dramatically increased the amount of reactive nitrogen $(\mathrm{N})$, such as inorganic ammonium $\left(\mathrm{NH}_{4}^{+}\right.$) and oxidized (e.g., nitrate: $\mathrm{NO}_{3}^{-}$) forms of $\mathrm{N}$, as well as its movement through ecosystems [1] [2] [3]. The large magnitude of this $\mathrm{N}$ production is problematic, as excess reactive $\mathrm{N}$ can be extremely detrimental to the functioning of various ecosystems [4]. For example, excessive plant growth due to nutrient enrichment is the primary environmental issue facing surface waters worldwide [5] [6] [7] [8] because it not only results in many undesirable ecological (e.g., species or salt-marsh loss) [9] and water quality (e.g., algal blooms, hypoxia or dead zones) [8] [10] problems but also causes high economic costs [11]. The eutrophication process is accelerated by human activity in densely populated urban or agricultural regions, where point $\mathrm{N}$ sources discharged from sewage treatment plants supplement high levels of non-point $\mathrm{N}$ sources produced from vehicles or fertilization [5], which is also referred to as cultural eutrophication [8].

In South Korea, the annual $\mathrm{N}$ input and output of agricultural areas were reported to be $1,259,515$ and 675,091 tons/yr, respectively. The annual $\mathrm{N}$ inputs of urban and forest area were 247,869 and 152,875 tons/yr, respectively, and the outputs were 90,319 and 65,794 tons/yr. For the past decade in South Korea, the $\mathrm{N}$ output of rivers and oceans was approximately 498,915 tons/yr, and the amount of nonpoint source pollutants equaled 367,640 tons/yr [12]. These phenomena can result in river and lake eutrophication due to excessive $\mathrm{N}$.

Atmospheric deposition is an important pathway for the input of $\mathrm{N}$ species into watersheds and water bodies. Atmospheric $\mathrm{N}$ deposition can cause soil and water body acidification, as well as leaching of $\mathrm{N}$ into surface and ground waters, resulting in eutrophication and water quality degradation. Wet deposition occurs through rain and snowfall, whereas dry atmospheric deposition arises from gaseous and particulate transport from the air to the surfaces of aquatic and terrestrial landscapes. Atmospheric deposition of nitrate $\mathrm{N}$ and ammonium $\mathrm{N}$ has been identified as a major factor in the decline of water quality in the watershed. The water quality in large rivers has deteriorated because of land use development over the past several decades and the dust fall from the atmosphere. In particular, mineral aerosols are deposited on land and streams via rainstorms during the summer as a result of the monsoon climate in South Korea.

In general, surface water and groundwater are affected by agricultural anthropogenic pollution resulting from the excessive use of pesticides and fertilizers and inadequate irrigation techniques. Although nitrate leaching in regions appears to be an inevitable process, an improvement in management practices leading to higher $\mathrm{N}$ fertilizer use efficiency is thought to reduce the potential for groundwater nitrate contamination. The environmental impact of agricultural pollutants depends on many different factors, such as fertilizer type, fixation, crop type, hydro-meteorological conditions (climatology and hydrogeology), crop management practices and soil characteristics [13]. Several authors have demonstrated the effect of different types of land cover on the hydrology of watersheds [14], a factor that is also directly linked to the nutrient transport within 
a watershed, particularly within the root zone.

For the multiple environmental processes involved in the dynamics of $\mathrm{N}$, such as atmosphere deposition and pesticide and fertilizer use, mathematical modeling is extremely valuable because it can help quantify the pollution, determine balances at the watershed scale and guide decisions to improve management [13] [15]. Thus, a model-based study is required to obtain information on the environmental effects considering anthropogenic data. The Soil and Water Assessment Tool (SWAT) model, which can be used for complex anthropogenic data, has been extensively applied in the literature. The SWAT model is considered one of the most useful models for long-term simulations in predominantly agricultural watersheds [16] and is robust in predicting nutrient losses at the watershed scale [15] [17].

In this study, among the available anthropogenic data (fertilizer, manure, fixation, sewage discharge and atmospheric deposition), the impact of the total $\mathrm{N}$ (T-N) load was evaluated to identify the effect of atmospheric, agricultural (fertilizer, manure, and fixation) and sewage discharge $\mathrm{N}$ loads on stream water quality at the watershed scale (Figure 1). The SWAT model was adopted and applied to a $6642 \mathrm{~km}^{2}$ study watershed.

\section{Materials and Methods}

\subsection{Description of the SWAT Model}

SWAT [18] is a physically based and continuous, long-term, distributed-para-

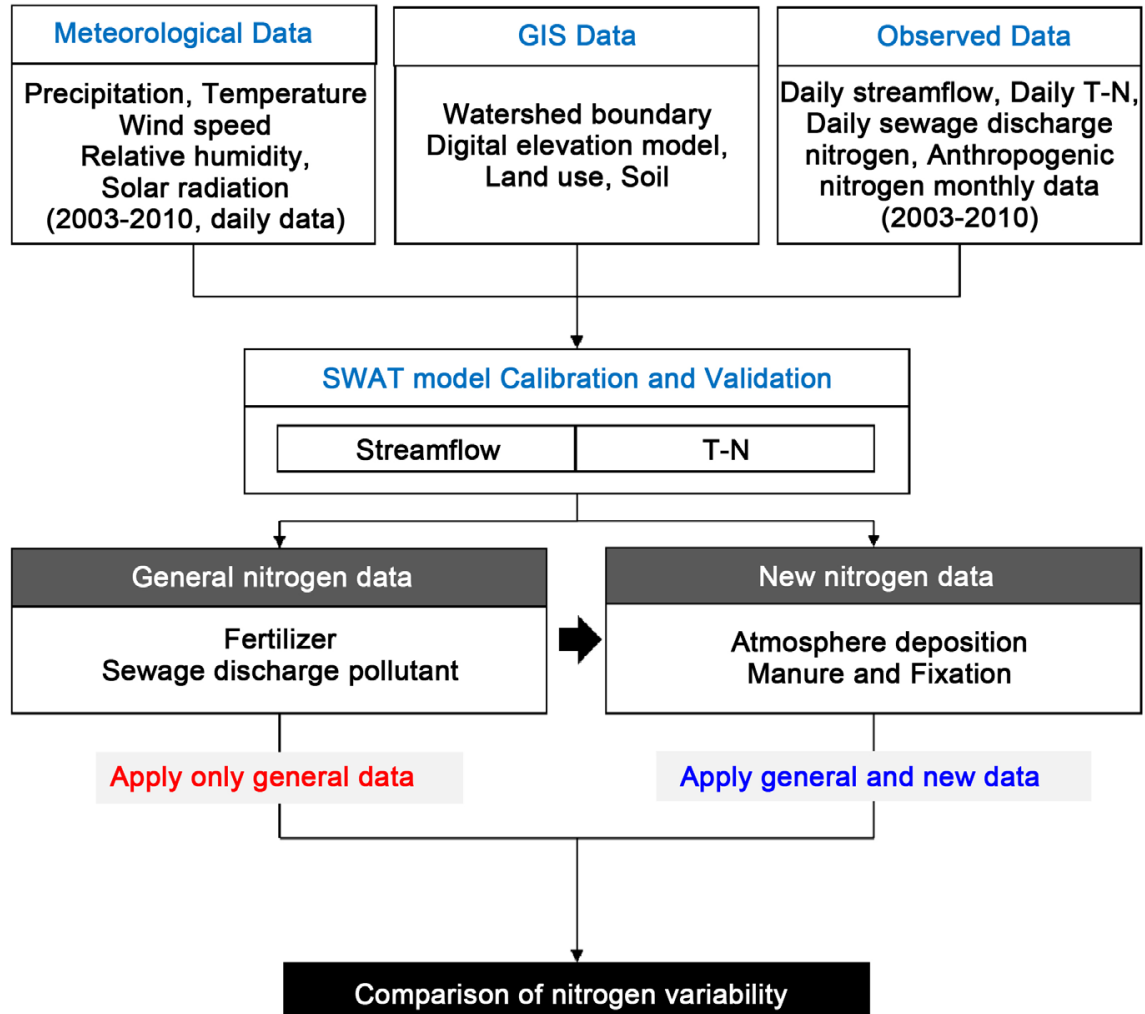

Figure 1. Flow chart of study process. 
meter model designed to predict the effects of land management practices on the hydrology and sediment and contaminant transport in agricultural watersheds with varying soils, land uses, and management conditions [18]. SWAT is based on the concept of hydrologic response units (HRUs), which are the portions of a sub-basin that possess unique land-use/management/soil attributes. The runoff, sediment, and nutrient loadings from each HRU are calculated separately using input data regarding weather, soil properties, topography, vegetation, and land management practices and then summed together to determine the total loadings from the sub-basin [19].

SWAT uses a modified version of the SCS-CN method (USDA-SCS 1972) and the Modified Universal Soil Loss Equation (MUSLE) [20] to predict runoff and sediment generation, respectively. SWAT simulates the organic and mineral $\mathrm{N}$ and phosphorus fractions by separating each nutrient into component pools, which can increase or decrease depending on the transformation and/or additions/losses occurring within each pool [21]. Mass balance is calculated on a daily time scale to capture the series of changes addressed through the respective process equations. Further details of the water balance, soil erosion, and nutrient process equations can be found in the SWAT theoretical documentation [22].

Atmospheric deposition occurs when airborne chemical compounds settle onto the land or water surface. Some of the most important chemical pollutants are those containing $\mathrm{N}$ or phosphorus. $\mathrm{N}$ compounds can be deposited onto water and land surfaces through both wet and dry deposition mechanisms. Wet deposition occurs through the absorption of compounds by precipitation as it falls, carrying mainly nitrate and ammonium. Dry deposition is the direct adsorption of compounds onto water or land surfaces and involves complex interactions between airborne $\mathrm{N}$ compounds and plant, water, soil, rock, or building surfaces. The atmospheric deposition by SWAT model is based on the following equations:

$$
\begin{gathered}
N O_{3 \text { rain }}=0.01 \cdot R_{\mathrm{NO3}} \cdot R_{\text {day }} \\
N H_{4 \text { rain }}=0.01 \cdot R_{\mathrm{NH} 4} \cdot R_{\text {day }} \\
N O_{3 l y=1}=N O_{3 l y=1}+N O_{3 \text { drydep }} \\
N H_{4 l y=1}=N H_{4 l y=1}+N H_{4 \text { drydep }}
\end{gathered}
$$

where $N H_{4 r a i n}$ is the nitrate added by rainfall ( $\left.\mathrm{kg} \mathrm{N} / \mathrm{ha}\right), R_{N H 4}$ is the concentration of ammonia in the rain $(\mathrm{mg} \mathrm{N} / \mathrm{L})$, and $R_{d a y}$ is the amount of precipitation on a given day $\left(\mathrm{mm} \mathrm{H}_{2} \mathrm{O}\right)$. The $\mathrm{N}$ in the rainfall is added to the ammonia pool in the top $10 \mathrm{~mm}$ of soil. $N O_{3 l y=1}$ is the nitrate in the surface soil layer, $N H_{4 l y=1}$ is the ammonium in the surface soil layer, $N O_{3 d r y d e p}$ is the daily nitrate dry deposition rate $(\mathrm{kg} / \mathrm{ha})$ and $N H_{4 d r y d e p}$ is the daily ammonium dry deposition rate $(\mathrm{kg} / \mathrm{ha})$.

\subsection{Description of the Study Watershed}

Figure 2 shows the Chungju dam watershed, which has a total area of $6642 \mathrm{~km}^{2}$ and is located in northeast South Korea, within the latitudes of $127.9^{\circ} \mathrm{E}$ to 


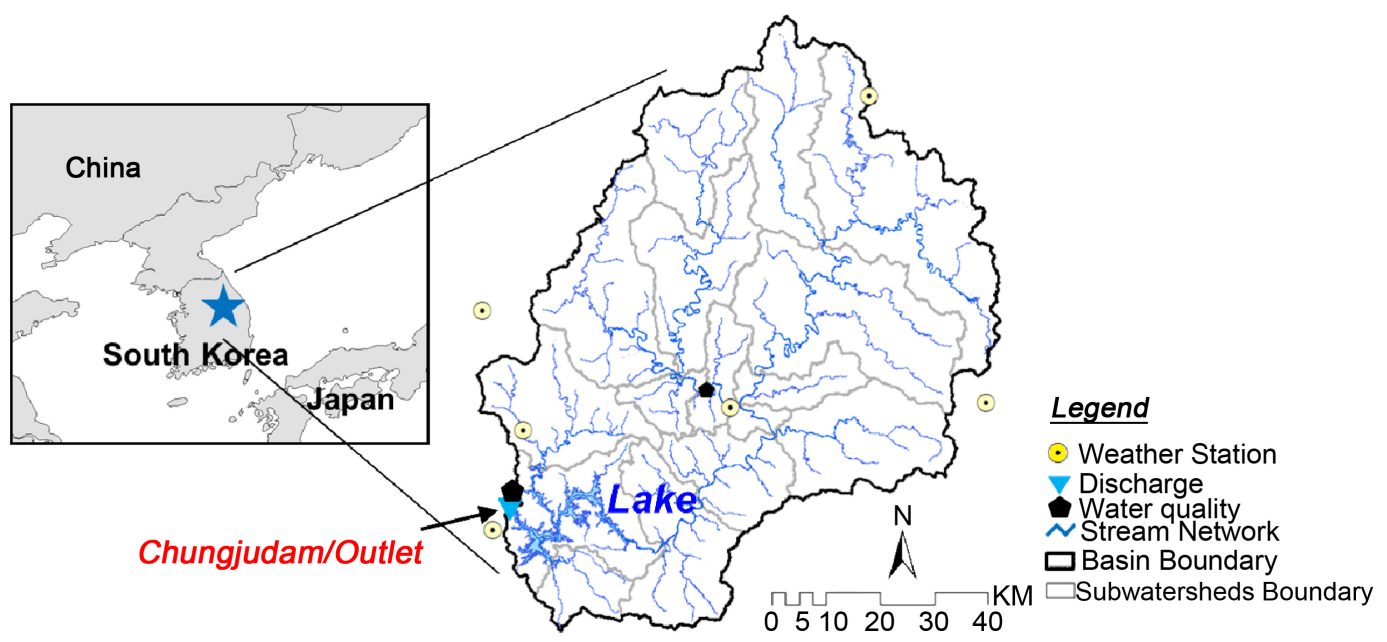

Figure 2. Location of study watershed and weather, streamflow, and water quality gauging stations.

$129.0^{\circ} \mathrm{E}$ and the longitudes of $36.8^{\circ} \mathrm{N}$ to $37.8^{\circ} \mathrm{N}$. The elevation ranges from 112 to $1562 \mathrm{~m}$, with an average slope of $37 \%$ and an average elevation of $609 \mathrm{~m}$. The 30 -year average annual precipitation is $1261 \mathrm{~mm}$, and the mean temperature is $9.4^{\circ} \mathrm{C}$. More than $82.3 \%\left(5469 \mathrm{~km}^{2}\right)$ of the watershed area is forested, and $12.2 \%$ $\left(811 \mathrm{~km}^{2}\right)$ is cultivated. The cultivated area consists of $728 \mathrm{~km}^{2}$ of paddy fields and $83 \mathrm{~km}^{2}$ of upland crops.

The elevation data were rasterized as a $100-\mathrm{m}$-resolution digital elevation model (DEM) from 1:5000 vector maps supplied by the Korea National Geography Institute. The soil data with respect to texture, depth, and drainage attributes were rasterized from 1:25,000 vector maps supplied by the Korea Rural Development Administration.

Thirty-four years (1977-2010) of daily weather data were collected from six ground weather stations. Daily streamflow data (2003-2010) at one location, located at the watershed outlet, were obtained from the Han River flood control office, and monthly water quality data at one location were obtained from the Korean Ministry of Environment to calibrate and validate the SWAT model.

The main indicator of stream water quality is the T-N (total $\mathrm{N}$ obtained as the sum of nitrate and particulate organic N losses) load. The eight-year (2003-2010) average sewage discharge $\mathrm{N}$ data for the modeling were prepared from each sewage discharge pollutant facility, including daily discharge rates and $\mathrm{N}$ load.

\subsection{Definition of Anthropogenic N Data}

\subsubsection{Atmospheric Deposition}

Table 1 shows the description of the $\mathrm{N}$ input data. To apply the anthropogenic data, the deposition, fixation, fertilizer, manure, and sewage discharge $\mathrm{N}$ were obtained from the Ministry of Environment, the Rural Development Administration (RDA), and the National Institute of Environmental Research (NIER). The obtained deposition $\mathrm{N}$ data were used to monitor acid deposition and to create the NEIR's impact assessment report (1999-2010). The dry and wet deposition $\mathrm{N}$ data were obtained from 39 stations in South Korea over a 12-year 
Table 1. Description of the nitrogen input data.

\begin{tabular}{|c|c|c|c|}
\hline Data & & Source & Period \\
\hline \multirow{3}{*}{$\begin{array}{l}\text { Deposition } \\
\text { (dry and wet) }\end{array}$} & $\mathrm{NO}_{3}^{-}$ & & \multirow{3}{*}{$1999-2010$} \\
\hline & $\mathrm{NH}_{4}^{+}$ & $\begin{array}{l}\text { Ministry of the Environment, } \\
\text { National Institute of Environmental Research (NIER) }\end{array}$ & \\
\hline & DON & & \\
\hline \multirow{2}{*}{$\begin{array}{l}\text { Fertilizer, } \\
\text { manure, and } \\
\text { fixation }\end{array}$} & $\begin{array}{l}\mathrm{NO}_{3}^{-} \\
\mathrm{NH}_{4}^{+}\end{array}$ & \multirow{2}{*}{$\begin{array}{l}\text { Ministry of the Environment, } \\
\text { NIER, } \\
\text { Rural Development Administration (RDA) }\end{array}$} & \multirow[t]{2}{*}{$1999-2010$} \\
\hline & DON & & \\
\hline \multirow{3}{*}{$\begin{array}{l}\text { Sewage dis- } \\
\text { charge }\end{array}$} & $\mathrm{NO}_{3}^{-}$ & \multirow{3}{*}{$\begin{array}{c}\text { Ministry of the Environment, } \\
\text { NIER }\end{array}$} & \multirow{3}{*}{$2008-2010$} \\
\hline & $\mathrm{NH}_{4}^{+}$ & & \\
\hline & DON & & \\
\hline
\end{tabular}

period. The wet deposition $\mathrm{N}$ load $\left(\mathrm{kg} / \mathrm{m}^{2} /\right.$ year) was estimated by multiplying the wet deposition concentration $(\mathrm{mg} / \mathrm{L})$ and the annual mean precipitation from each station. The dry deposition $\mathrm{N}$ was distributed according to the ratio of urban to total dry deposition in South Korea. Total deposition N (wet + dry) was divided into $\mathrm{NO}_{3}^{-}, \mathrm{NH}_{4}^{+}$, and dissolved organic nitrogen (DON) according to Van Breemen et al. [23].

\subsubsection{Fertilizer, Manure, and Fixation}

Fertilizer and manure $\mathrm{N}$ data were obtained from the Statistical Yearbook of Agriculture and Forestry (1999-2010) of the RDA. The fixation N data used 35 and $15 \mathrm{~kg} / \mathrm{ha} / \mathrm{yr}$ [24] [25]. The fertilizer $\mathrm{N}$ data were obtained from administrative districts from the Statistical Yearbook of Agriculture and Forestry (Rural Development Administration, 1999-2010), and the manure N data were based on the Total Water Pollution Load Management Guidelines (1999-2010) from the NIER. The livestock waste pollutant load was estimated as follows:

Livestock wastewater pollutant load

$=\sum($ Livestock facilities numbers $\times$ Livestock facilities wastewater pollutant unit load $)$

Livestock solid pollutant load

$=\sum($ Livestock facilities numbers $\times$ Livestock facilities solid pollutant unit load $)$

Livestock pollutant load

$=$ Livestock wastewater pollutant load + Livestock solid pollutant load

Final manure pollutant load

$=$ Livestock pollutant load $\times$ ratio of agriculture resource $(0.9)$

This study assumed that final manure pollutant load used only $90 \%$ of the livestock pollutant load considering agriculture resources. Thus, the final manure pollutant load was obtained according to Equation (8). Sewage discharge $\mathrm{N}$ data from the river were based on the daily $\mathrm{N}$ discharge data from 3227 stations in South Korea for 12 years (1999-2010). 


\section{Results and Discussion}

\subsection{Calibration and Validation of the SWAT Model}

The SWAT model was calibrated based on 4 years (2003-2006) of daily streamflow data at the watershed outlet and then validated using another 4 years (2007-2010) of data. We used the same calibrated parameters as Park et al. [26] for both streamflow and T-N. The calibrated model parameters are shown in Table 2. Sensitivity Of parameters was analyzed by comparing ratio (\%) of runoff changes. By comparing ratio (\%) of changes simulated runoff from adjusted value, the ratio of change more than $70 \%$ or $50 \%$ defined high or medium sensitivity.The ESCO was sensitive to the peak flow and the amount of discharge. GW_DELAY and ALPHA_BF affected the recession phase of the hydrograph. These parameters were then used to validate the SWAT model to determine its efficiency. The decision process of the calibrated parameters and the sensitivity analysis are detailed in Park et al. [26]. A statistical summary of the 8 years of observed versus simulated streamflow is shown in Table 3. Figure 3

Table 2. SWAT calibrated parameters.

\begin{tabular}{|c|c|c|c|c|c|c|}
\hline & Parameter & Definition & LB & UB & Sensitivity & $\begin{array}{l}\text { Adjusted } \\
\text { Value }\end{array}$ \\
\hline \multirow{5}{*}{ Q } & ESCO & Soil evaporation compensation factor & 0 & 1 & High & 0 \\
\hline & ALPHA_BF & $\begin{array}{l}\text { Baseflow alpha factor for land with slow } \\
\text { response to recharge }\end{array}$ & 0 & 1 & High & 0.05 \\
\hline & RCHRG_DP & Deep aquifer percolation fraction & 0 & 1 & Medium & 0.6 \\
\hline & GW_DELAY & Groundwater delay & 0 & 500 & High & 31 \\
\hline & GW_REVAP & Groundwater "revap" coefficient & 0.02 & 0.2 & Medium & 0.02 \\
\hline \multirow{3}{*}{ SN } & SMFMX & Maximum snowmelt rate & 1.4 & 6.9 & Medium & 4.5 \\
\hline & SMFMN & Minimum snowmelt rate & 1.4 & 6.9 & Medium & 4.5 \\
\hline & SMTMP & Snowmelt base temperature & -5 & 5 & High & 1.5 \\
\hline
\end{tabular}

Q: Streamflow, SN: Snow parameter, LB: Lower bound, UB: Upper bound.

Table 3. Statistical summary of observed versus SWAT simulated streamflow for calibration (C) and validation (V) periods.

\begin{tabular}{ccccccccc}
\hline \multirow{2}{*}{ Year } & \multirow{2}{*}{$\begin{array}{c}\text { PCP } \\
(\mathrm{mm})\end{array}$} & \multicolumn{2}{c}{ Discharge $(\mathrm{mm})$} & \multicolumn{2}{c}{ Runoff ratio (\%) } & \multirow{2}{*}{ NSE } & \multirow{2}{*}{$\mathrm{R}^{2}$} & \multirow{2}{*}{ Note } \\
\cline { 3 - 6 } & & Obs. & SWAT & Obs. & SWAT & & & \\
\hline 2003 & 1598.3 & 1051.1 & 811.4 & 65.8 & 50.8 & 0.77 & 0.79 & $\mathrm{C}$ \\
2004 & 1542.0 & 911.5 & 714.9 & 59.1 & 46.4 & 0.74 & 0.74 & $\mathrm{C}$ \\
2005 & 1494.4 & 743.1 & 626.2 & 49.7 & 41.9 & 0.74 & 0.76 & $\mathrm{C}$ \\
2006 & 1348.0 & 954.6 & 826.6 & 70.8 & 61.3 & 0.75 & 0.75 & $\mathrm{C}$ \\
2007 & 1475.6 & 1016.5 & 1009.1 & 68.9 & 68.4 & 0.71 & 0.75 & $\mathrm{~V}$ \\
2008 & 950.7 & 403.4 & 318.4 & 42.4 & 33.5 & 0.74 & 0.84 & V \\
2009 & 1168.0 & 613.2 & 570.6 & 52.5 & 48.9 & 0.72 & 0.67 & V \\
2010 & 1258.5 & 809.1 & 728.5 & 64.3 & 57.9 & 0.74 & 0.75 & V \\
Mean & 1354.4 & 812.8 & 700.7 & 59.2 & 51.1 & 0.74 & 0.76 & - \\
\hline
\end{tabular}

PCP: Precipitation, Obs.: Observed, $\mathrm{R}^{2}$ : determination of coefficient, NSE: Nash-Sutcliffe efficiency, C: Calibration period, V: Validation period. 


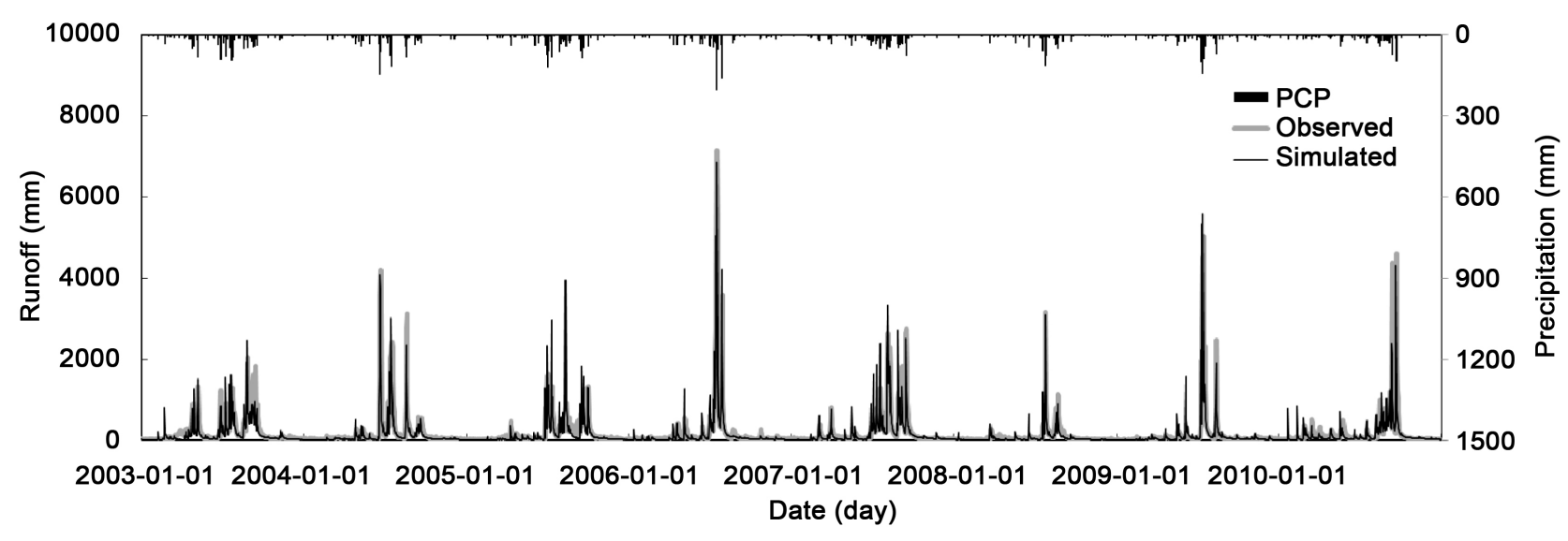

Figure 3. Comparison between observed and SWAT simulated streamflow results.

shows the observed versus simulated streamflow. The Nash and Sutcliffe [27] efficiency (NSE) for streamflow during the validation period was 0.74 , and the coefficient of determination $\left(\mathrm{R}^{2}\right)$ was 0.76 .

\subsection{Comparison of the Nitrogen Dynamics}

The $\mathrm{N}$ input datasets involve three anthropogenic $\mathrm{N}$ sources: atmospheric deposition, agriculture $\mathrm{N}$ (fertilizer + manure + fixation), and sewage discharge $\mathrm{N}$. For each watershed, which consists of various land uses, the atmospheric deposition $\mathrm{N}$ input was applied to all the lands, whereas the agricultural $\mathrm{N}$ inputs were applied to only the upland crop and paddy lands. The sewage discharge $\mathrm{N}$ input was directly applied to the river reaches. Each of the $\mathrm{N}$ species for the three $\mathrm{N}$ sources was applied to the corresponding terrestrial and river pools.

Table 4 shows the SWAT-calibrated parameters related to anthropogenic N. Table 5 shows the T-N load (ton/year) that has a practical impact on the portion of input $\mathrm{N}$ in the watershed. The atmospheric deposition load comprised a large portion of the total input $\mathrm{N}$. The deposition resulted in a large input $\mathrm{N}$ load into the watershed because wet deposition and dry deposition primarily decreased along with rainfall and yellow sand containing $\mathrm{N}$ particles through the total watershed in South Korea. The fertilizer, manure, and fixation were only consumed in the agriculture area during a specific period each year.

This study applied five cases based on the anthropogenic $\mathrm{N}$ data. Case 1 is scenario before all anthropogenic $\mathrm{N}$ data were applied, case 2 is a scenario after the sewage discharge $\mathrm{N}$ data were applied, case 3 is a scenario after the atmospheric deposition data were applied, case 4 is a scenario after the fertilizer, manure, and fixation data were applied, and case 5 is a scenario after all anthropogenic $\mathrm{N}$ data were applied. Figure 4 and Table 6 show the observed and simulated daily T-N at the watershed outlet. The average $\mathrm{R}^{2}$ values of T-N during the calibration and validation periods were 0.33 (case 1) and 0.69 (case 5), respectively. The $\mathrm{R}^{2}$ for the T-N results increased by 0.36 after the anthropogenic $\mathrm{N}$ data were applied. The results indicated that cases 2 and 3 affected the baseflow and recession of $\mathrm{T}-\mathrm{N}$, respectively. 
Table 4. SWAT calibrated parameters related to anthropogenic nitrogen.

\begin{tabular}{ccccc}
\hline \multirow{2}{*}{ Parameter } & Definition & Default & $\begin{array}{c}\text { Adjusted } \\
\text { Value }\end{array}$ \\
\hline \multirow{2}{*}{ RAMMO_SUB } & $\begin{array}{c}\text { Atmospheric deposition of ammonium }(\mathrm{mg} / \mathrm{L}) \\
\text { values for the entire watershed }\end{array}$ & 0 & 3 \\
& RCN_SUB & $\begin{array}{c}\text { Concentration of nitrate in the } \\
\text { precipitation }(\mathrm{mg} / \mathrm{L})\end{array}$ & 0 & 4.5 \\
$\begin{array}{c}\text { Anthropogenic } \\
\text { nitrogen }\end{array}$ & DRYDEP_NH4 & Nitrate dry deposition rate $(\mathrm{kg} / \mathrm{ha} / \mathrm{yr})$ & 0 & 4.3 \\
& DRYDEP_NO3 & Ammonia dry deposition rate $(\mathrm{kg} / \mathrm{ha} / \mathrm{yr})$ & 0 & 4 \\
& FIXCO & Nitrogen fixation coefficient & 0 & 1 \\
& NFIXMX & Maximum daily N fixation $(\mathrm{kg} / \mathrm{ha})$ & 0 & 3.3 \\
& FRT_KG & Amount of fertilizer applied & 0 & 257.4 \\
\hline
\end{tabular}

Table 5. Process of calculating the average nitrogen input total load (tons/year).

\begin{tabular}{ccc}
\hline N input & Calculation process & $\begin{array}{c}\text { Total load } \\
\text { (tons/year) }\end{array}$ \\
\hline Deposition & dry deposition $(8.3 \mathrm{~kg} / \mathrm{ha} / \mathrm{yr}) \times$ total area $\left(6642 \mathrm{~km}^{2}\right)$ & $30,589.7$ \\
& wet deposition $(3 \mathrm{mg} / \mathrm{L}) \times$ total area $\left(6642 \mathrm{~km}^{2}\right) \times$ annual \\
precipitation $(1258.3 \mathrm{~mm} / \mathrm{yr})$ & $(60.0 \%)$ \\
Fertilizer and & fertilizer and manure nitrogen $(257.4 \mathrm{~kg} / \mathrm{ha} / \mathrm{yr}) \times$ agriculture & \\
Manure & area $\left.(783.5 \mathrm{~km})^{2}\right)$ & $20,167.3$ \\
Fixation & upland crop and paddy area $(3.3 \mathrm{~kg} / \mathrm{ha} / \mathrm{yr}) \times$ agriculture area & $(39.0 \%)$ \\
Sewage & $(783.5 \mathrm{~km})$ & \\
discharge & Sewage discharge nitrogen $(126.0 \mathrm{~kg} /$ day $) \times$ year $(365$ days $)$ & $(1.0 \%)$ \\
\hline
\end{tabular}

Table 6. Summary of yearly T-N loads for five cases.

\begin{tabular}{ccccccccccccc}
\hline \multirow{2}{*}{ Year } & Observed & \multicolumn{2}{c}{ Case 1} & \multicolumn{2}{c}{ Case 2} & \multicolumn{2}{c}{ Case 3} & \multicolumn{2}{c}{ Case 4} & \multicolumn{2}{c}{ Case 5} \\
\cline { 2 - 12 } & $\begin{array}{c}\text { Total } \\
(\text { tons })\end{array}$ & $\begin{array}{c}\text { Total } \\
(\mathrm{kg})\end{array}$ & $\mathrm{R}^{2}$ & $\begin{array}{c}\text { Total } \\
(\mathrm{kg})\end{array}$ & $\mathrm{R}^{2}$ & $\begin{array}{c}\text { Total } \\
(\mathrm{kg})\end{array}$ & $\mathrm{R}^{2}$ & $\begin{array}{c}\text { Total } \\
(\mathrm{kg})\end{array}$ & $\mathrm{R}^{2}$ & $\begin{array}{c}\text { Total } \\
(\mathrm{kg})\end{array}$ & $\mathrm{R}^{2}$ \\
\hline 2003 & 836.9 & 78.5 & 0.45 & 80.2 & 0.46 & 200.9 & 0.77 & 91.4 & 0.46 & 288.1 & 0.77 \\
2004 & 2460.2 & 482.7 & 0.80 & 490.3 & 0.80 & 1224.3 & 0.67 & 539.1 & 0.84 & 1673.0 & 0.70 \\
2005 & 1564.3 & 303.0 & 0.20 & 309.3 & 0.21 & 1083.0 & 0.60 & 417.4 & 0.18 & 1552.6 & 0.66 \\
2006 & 954.2 & 133.6 & 0.27 & 139.1 & 0.29 & 568.5 & 0.77 & 206.8 & 0.44 & 847.5 & 0.82 \\
2007 & 1848.3 & 384.2 & 0.19 & 390.6 & 0.22 & 1122.0 & 0.77 & 450.6 & 0.18 & 1565.4 & 0.78 \\
2008 & 742.9 & 133.4 & 0.19 & 139.4 & 0.20 & 490.7 & 0.61 & 180.3 & 0.25 & 751.2 & 0.62 \\
2009 & 2189.8 & 292.1 & 0.51 & 297.8 & 0.56 & 981.2 & 0.62 & 329.6 & 0.65 & 1335.8 & 0.65 \\
2010 & 1092.9 & 1001.1 & 0.03 & 1007.0 & 0.01 & 1120.8 & 0.29 & 1087.5 & 0.02 & 1540.1 & 0.50 \\
Mean & 1461.2 & 351.1 & 0.33 & 356.7 & 0.34 & 848.9 & 0.64 & 412.8 & 0.38 & 1194.2 & 0.69 \\
\hline
\end{tabular}

Case 1: scenario that excluded all anthropogenic N, Case 2: scenario that applied only sewage discharge $\mathrm{N}$, Case 3: scenario that applied only atmospheric deposition $\mathrm{N}$, Case 4: scenario that applied only agriculture $\mathrm{N}$, Case 5: scenario that applied all anthropogenic N. 


\subsection{Analysis of the Nitrogen Changes}

In this study, the load duration curve (LDC) method was used to determine the variability of T-N (Figure 5 and Table 7). The LDC method was used to describe the change in high, middle, and low T-N durations. Table 7 provides the monthly T-N loads and the percentage change by comparing the scenarios. Case 2, case 3, case 4, and case 5 exhibit percentage changes of 4.4, 112.3, 19.7 and $201.7 \%$, respectively (Table 7). As a result, cases 3 and 4 tended to be affected by rainfall and the fertilizer period from April. The LDC graph in Figure 5 illustrates that the major differences between case 1 and case 2 appeared during the

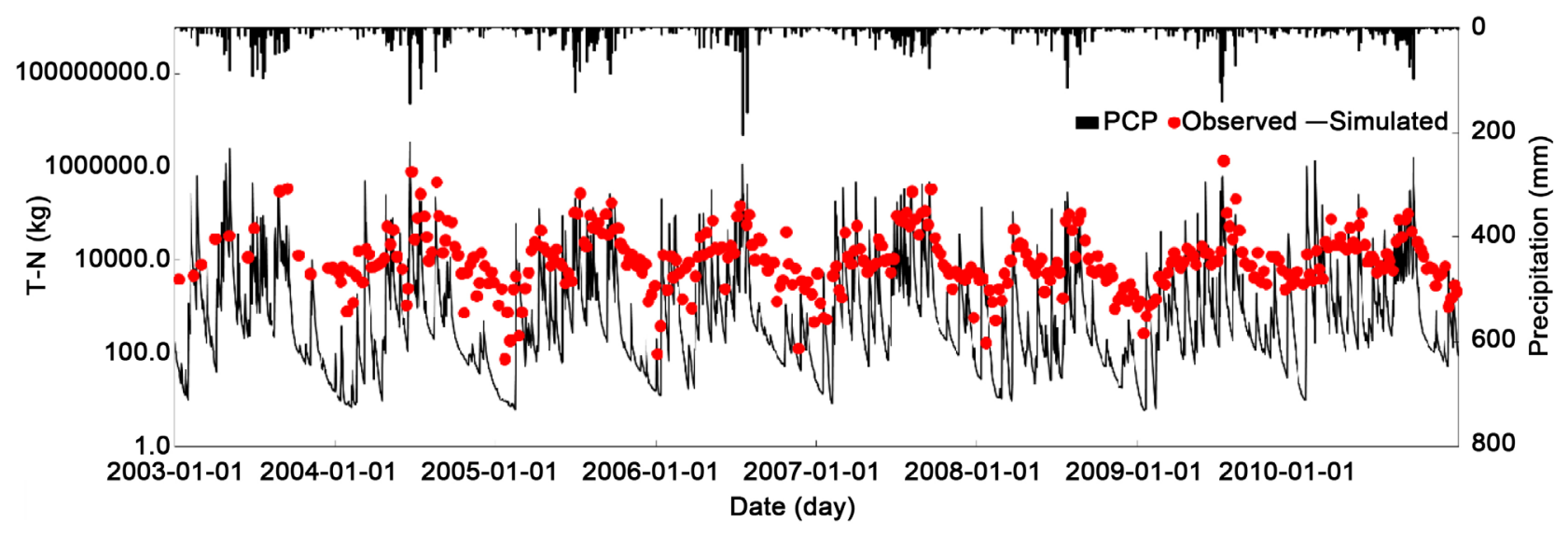

(a)

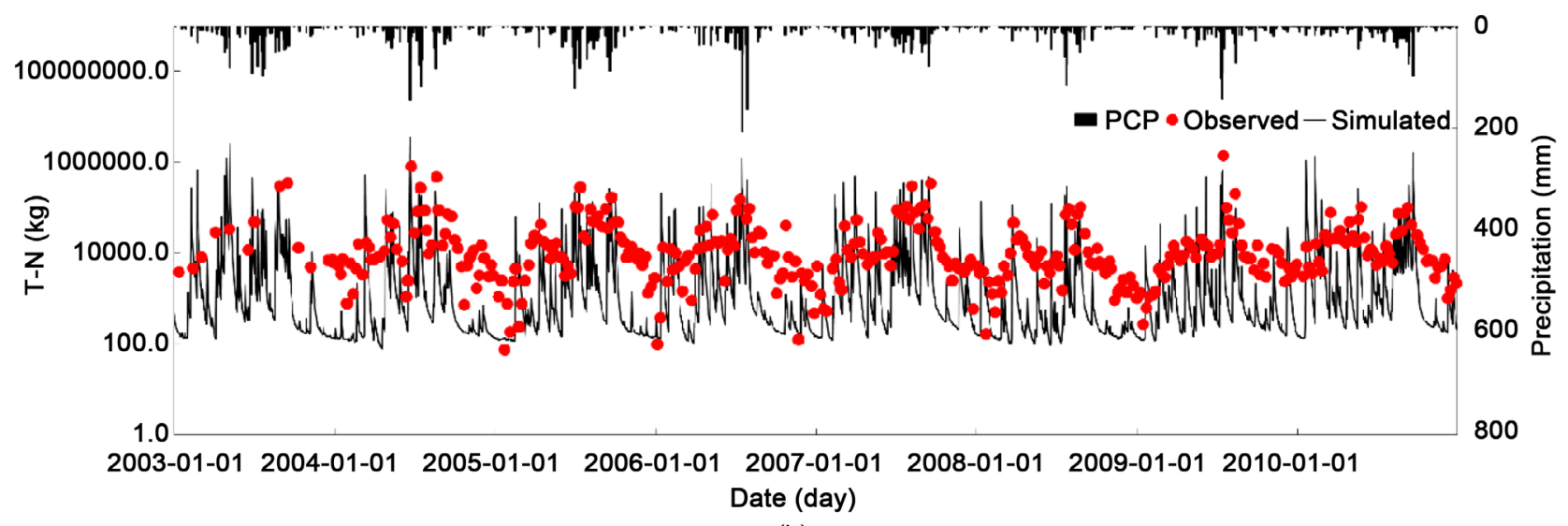

(b)
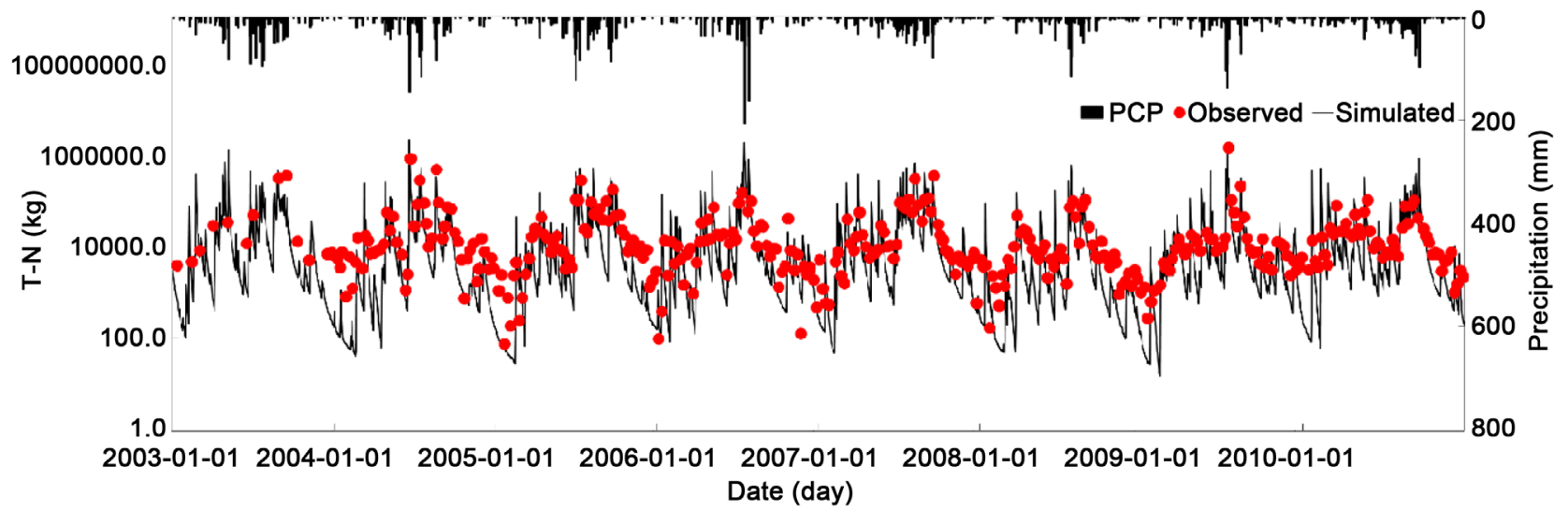

800

(c) 


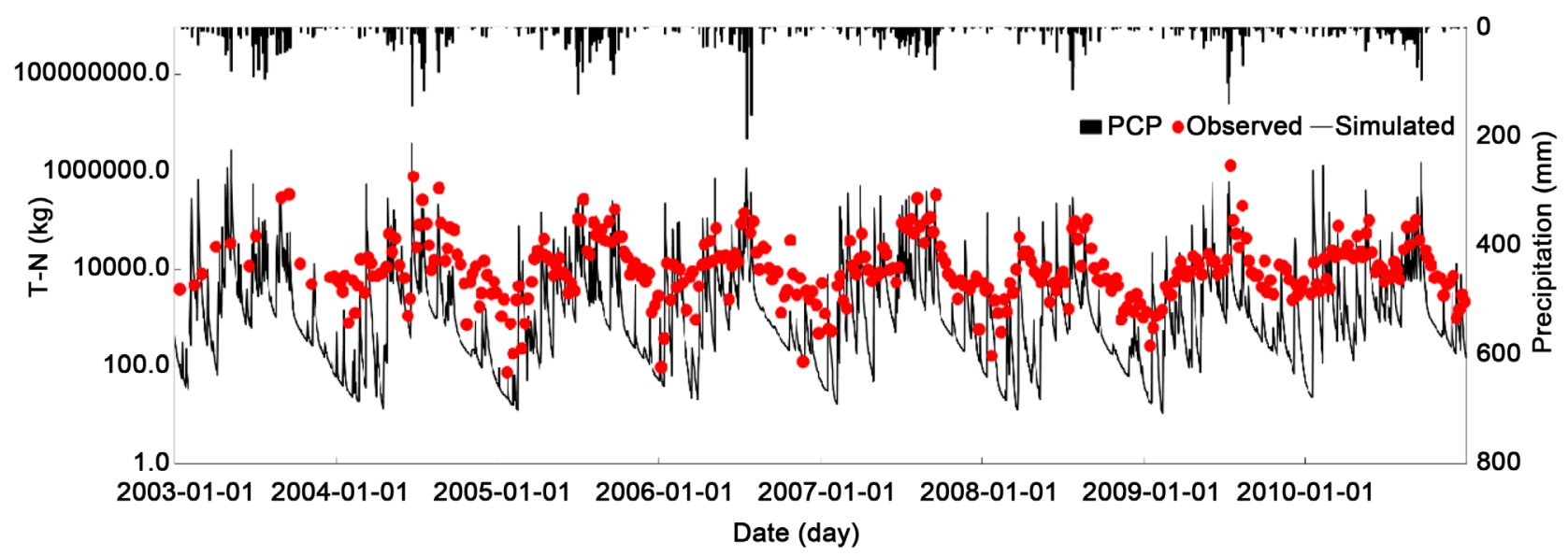

(d)

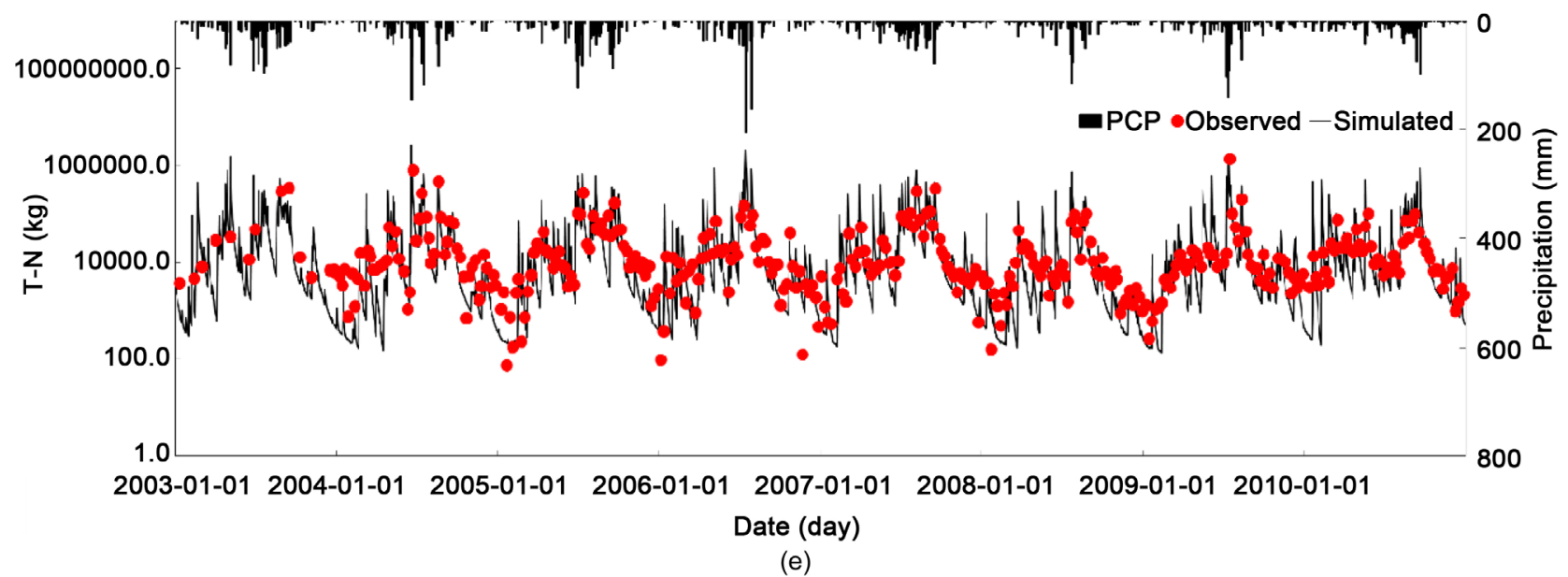

Figure 4. Comparison of observed and SWAT simulated T-N using anthropogenic data: (a) case 1, (b) case 2, (c) case 3, (d) case 4, and (e) case 5 .

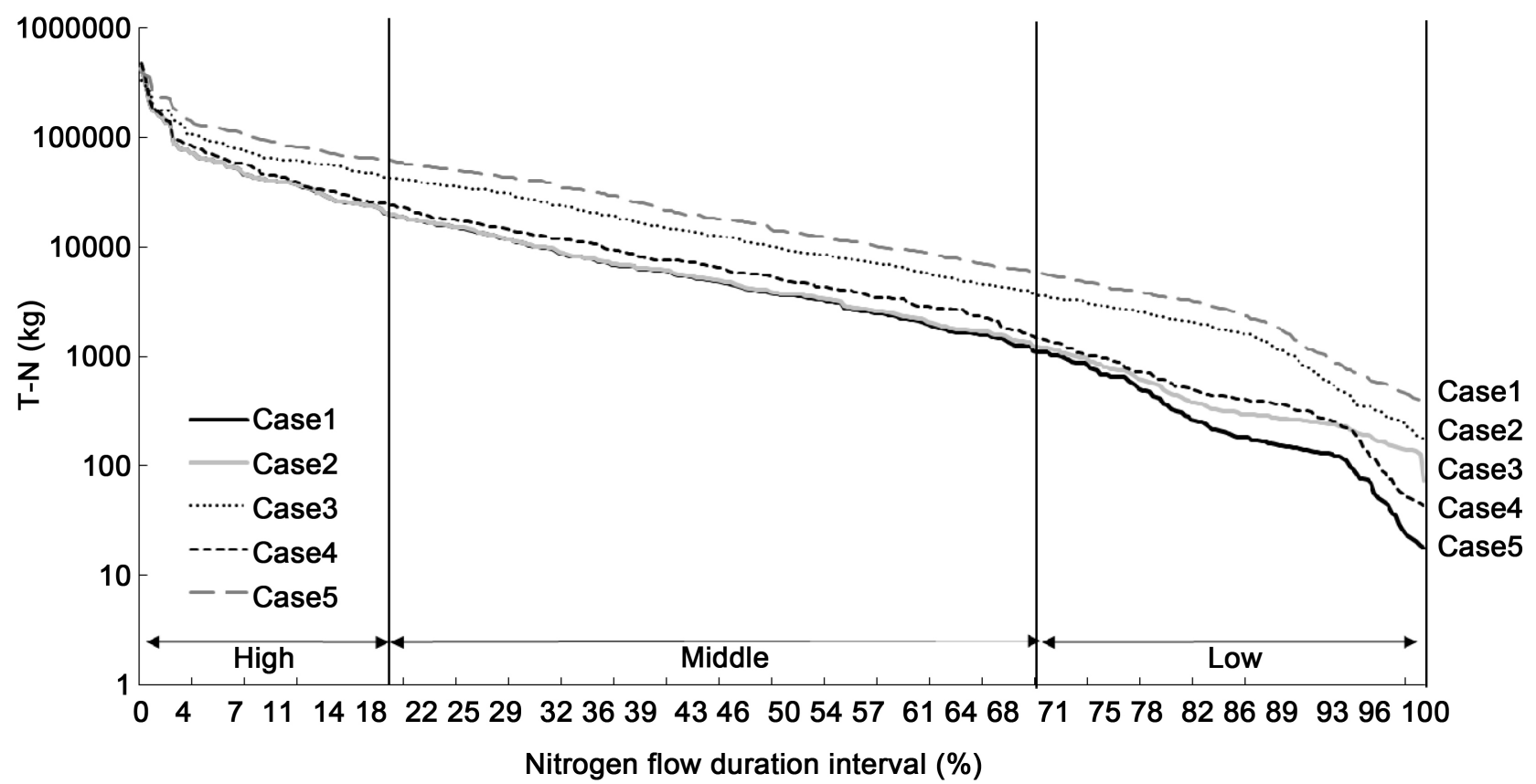

Figure 5. Comparison of T-N load duration graph for five cases. 
Table 7. Percentage changes in monthly $\mathrm{T}-\mathrm{N}$ for five cases.

\begin{tabular}{cccccccccc}
\hline & Case 1 & \multicolumn{2}{c}{ Case 2 } & \multicolumn{2}{c}{ Case 3 } & \multicolumn{2}{c}{ Case 4} & \multicolumn{2}{c}{ Case 5 } \\
\cline { 2 - 10 } Month & $\begin{array}{c}\text { Total } \\
(\text { ton })\end{array}$ & $\begin{array}{c}\text { Total } \\
(\mathrm{kg})\end{array}$ & $\begin{array}{c}\text { Change } \\
(\%)\end{array}$ & $\begin{array}{c}\text { Total } \\
(\mathrm{kg})\end{array}$ & $\begin{array}{c}\text { Change } \\
(\%)\end{array}$ & $\begin{array}{c}\text { Total } \\
(\mathrm{kg})\end{array}$ & $\begin{array}{c}\text { Change } \\
(\%)\end{array}$ & $\begin{array}{c}\text { Total } \\
(\mathrm{kg})\end{array}$ & $\begin{array}{c}\text { Change } \\
(\%)\end{array}$ \\
\hline 1 & 283.5 & 287.3 & +1.3 & 133.6 & -52.9 & 298.0 & +4.5 & 154.9 & -45.4 \\
2 & 611.2 & 614.7 & +0.6 & 361.8 & -40.8 & 638.9 & +6.1 & 436.3 & -28.6 \\
3 & 293.3 & 296.9 & +1.2 & 399.5 & +36.2 & 311.3 & +6.7 & 498.3 & +69.9 \\
4 & 485.4 & 489.0 & +0.7 & 656.4 & +35.2 & 517.8 & +53.9 & 824.4 & +69.8 \\
5 & 724.8 & 728.1 & +0.5 & 824.5 & +13.8 & 1115.2 & +22.2 & 1405.5 & +93.9 \\
6 & 923.3 & 925.7 & +0.3 & 898.1 & -2.7 & 1127.9 & +13.4 & 1359.1 & +47.2 \\
7 & 1163.6 & 1165.5 & +0.2 & 3178.0 & +173.1 & 1319.4 & -5.2 & 4240.7 & +264.5 \\
8 & 569.4 & 572.7 & +0.6 & 1713.0 & +200.8 & 539.7 & +0.8 & 2272.0 & +299.0 \\
9 & 750.8 & 753.9 & +0.4 & 1291.7 & +72.0 & 756.8 & +29.7 & 1691.4 & +125.3 \\
10 & 30.6 & 34.2 & +11.8 & 155.2 & +406.6 & 39.7 & +39.3 & 229.8 & +650.3 \\
11 & 20.8 & 24.4 & +17.5 & 100.4 & +383.0 & 29.0 & +35.3 & 149.7 & +620.1 \\
12 & 21.1 & 24.8 & +17.7 & 47.1 & +123.5 & 28.5 & +4.5 & 74.5 & +253.8 \\
Mean & 489.8 & 493.1 & +4.4 & 813.3 & +112.3 & 560.2 & +19.7 & 1111.4 & +201.7 \\
\hline
\end{tabular}

Case 1: scenario that excluded all anthropogenic $\mathrm{N}$, Case 2: scenario that applied only sewage discharge $\mathrm{N}$, Case 3: scenario that applied only atmospheric deposition $\mathrm{N}$, Case 4: scenario that applied only agriculture $\mathrm{N}$, Case 5: scenario that applied all anthropogenic $\mathrm{N}$.

low T-N period in the dry season. When the results of case 1 and case 2 were compared, we found that sewage discharge pollution affected the T-N discharged with the baseflow during the low T-N period.

Compared to case 1, case 3 exhibited increases of $41.6 \%$ (high duration), $156.1 \%$ (middle duration), and $402.0 \%$ (low duration); case 4 exhibited increases of $10.8 \%$ (high duration), $27.7 \%$ (middle duration), and $55.9 \%$ (low duration); and case 5 exhibited increases of $87.3 \%$ (high duration), 272.6\% (middle duration), and $677.9 \%$ (low duration).

\section{Summary and Conclusions}

In this study, the SWAT model was used to simulate the discharge and T-N load in the Chungju dam watershed outlet for the 2003-2010 period, and the impact of the T-N load was evaluated to identify the effects of atmospheric, agricultural (fertilizer, manure, fixation) and sewage discharge $\mathrm{N}$ loads on the stream water quality at the watershed scale. The SWAT model was established using all available data on the $\mathrm{N}$ stores in the fertilizer, manure, fixation, sewage discharge $\mathrm{N}$, and atmospheric deposition. The SWAT model was prepared by calibrating and validating 8 years (2003-2010) of downstream streamflow and T-N data; the model can evaluate the $\mathrm{N}$ loads at depth considering atmosphere deposition. The $\mathrm{N}$-input datasets were three anthropogenic $\mathrm{N}$ sources, namely, atmospheric deposition, agriculture $\mathrm{N}$ (fertilizer + manure + fixation), and sewage discharge $\mathrm{N}$.

The SWAT model was calibrated for 4 years (2003-2006) of daily streamflow 
data at the watershed outlet and validated using another 4 years of data (20072010). The SWAT parameters were used to validate the SWAT model to determine its efficiency. The NSE for streamflow during the validation period was 0.74 , and the $\mathrm{R}^{2}$ was 0.76 . This study applied five cases based on the anthropogenic $\mathrm{N}$ data to determine their impact on water quality. The LDC method and monthly T-N were analyzed for the variable T-N. The LDC method was used to describe the percentage change in high, middle, low T-N durations. Compared to case 1 , the percentage changes for case 2 , case 3 , case 4 , and case 5 were $4.4 \%$, $112.3 \%, 19.7 \%$ and $201.7 \%$, respectively. As a result, case 3 and case 4 tended to be affected by rainfall and the fertilizer period from April. The major differences between case 1 and case 2 appeared during the low-N period in the dry season. Atmospheric deposition data increased the overall $\mathrm{T}-\mathrm{N}$, following the rainfall trend.

The data collected from national reports and applied to the SWAT database can be utilized, and the $\mathrm{N}$ dynamics between the atmosphere and land were successfully determined even though SWAT uses data based on annual values. In the long term, $\mathrm{N}$ generally follows the trends in fertilization, atmospheric deposition, and sewage discharge N. The SWAT hydrological model was successfully used to produce the historical and future trends in $\mathrm{N}$ load. The achievement of this study has not been reported to date. The results of this study also indicate that the modeling of $\mathrm{N}$ dynamics at the watershed and small-scale sub-basin scales can provide a valuable link between the atmosphere and land.

\section{Acknowledgements}

This research was supported by a grant (16AWMP-B079625-03) from the Water Management Research Program funded by the Ministry of Land, Infrastructure and Transport of the Korean government.

\section{References}

[1] Galloway, J.N., Dentener, F.J., Capone, D.G., Boyer, E.W., Howarth, R.W., Seitzinger, S.P., Asner, G.P., Cleveland, C.C., Green, P.A., Holland, E.A., Karl, D.M., Michaels, A.F., Porter, J.H., Townsend, A.R. and Vöosmarty, C.J. (2004) Nitrogen Cycles: Past, Present, and Future. Biogeochemistry, 70, 153-226.

https://doi.org/10.1007/s10533-004-0370-0

[2] Galloway, J.N., Townsend, A.R., Erisman, J.W., Bekunda, M., Cai, Z., Freney, J.R., Martinelli, L.A., Seitzinger, S.P. and Sutton, M.A. (2008) Transformation of the Nitrogen Cycle: Recent Trends, Questions, and Potential Solutions. Science, 320, 889892. https://doi.org/10.1126/science.1136674

[3] Smil, V. (1999) Nitrogen in Crop Production: An Account of Global Flows. Global Biogeochemical Cycles, 13, 647-662. https://doi.org/10.1029/1999GB900015

[4] Galloway, J.N., Aber, J.D., Erisman, J.W., Seitzinger, S.P., Howarth, R.W., Cowling, E.B. and Cosby, B.J. (2003) The Nitrogen Cascade. BioScience, 53, 341-356.

[5] Howarth, R.W., Sharpley, A. and Walker, D. (2002) Sources of Nutrient Pollution to Coastal Waters in the United States: Implications for Achieving Coastal Water Quality Goals. Estuaries, 25, 656-676. https://doi.org/10.1007/BF02804898

[6] Smith, V.H. (2003) Eutrophication of Freshwater and Coastal Marine Ecosystems: 
A Global Problem. Environmental Science and Pollution Research International, 10, 126-139.

[7] Smith, V.H., Joye, S.B. and Howarth, R.W. (2006) Eutrophication of Freshwater and Marine Ecosystems. Limnology and Oceanography, 51, 351-355. https://doi.org/10.4319/lo.2006.51.1_part_2.0351

[8] Smith, V.H. and Schindler, D.W. (2009) Eutrophication Science: Where do We Go from Here? Trends in Ecology and Evolution, 24, 201-207. https://doi.org/10.1016/j.tree.2008.11.009

[9] Vonlanthen, P., Bittner, D., Hudson, A.G., Young, K.A., Müller, R., LundsgaardHansen, B., Roy, D., Di Piazza, S., Largiader, C.R. and Seehausen, O. (2012) Eutrophication Causes Speciation Reversal in Whitefish Adaptive Radiations. Nature, 482, 357-362. https://doi.org/10.1038/nature10824

[10] Diaz, R.J. and Rosenberg, R. (2008) Spreading Dead Zones and Consequences for Marine Ecosystems. Science, 321, 926-929.

[11] Pretty, J.N., Mason, C.F., Nedwell, D.B., Hine, R.E., Leaf, S. and Dils, R. (2003) Environmental Costs of Freshwater Eutrophication in England and Wales. Environmental Science and Technology, 37, 201-208. https://doi.org/10.1021/es020793k

[12] National Institute of Environmental Research (2012) The Report on National Water Quality Evaluation 2012. Ministry of Environment, Seoul.

[13] Jégo, G., Martínez, M., Antigüedad, I., Launay, M., Sanchez-Pérez, J.M. and Justes, E. (2008) Evaluation of the Impact of Various Agricultural Practices on Nitrate Leaching Under the Root Zone of Potato and Sugar Beet Using the STICS Soil-Crop Model. Science of the Total Environment, 394, 207-221. https://doi.org/10.1016/j.scitotenv.2008.01.021

[14] Pikounis, M. (2003) Application of the SWAT Model in the Pinos River Basin Under Different Land Use Cases. Global Nest Journal, 5, 71-79.

[15] Cerro, I., Sanchez-Perez, J.M., Ruiz-Romera, E. and Antigüedad, I. (2014) Variability of Particulate (SS, POC) and Dissolved (DOC, $\mathrm{NO}_{3}$ ) Matter during Storm Events in the Alegria Agricultural Watershed. Hydrological Processes, 28, 2855-2867.

[16] Borah, D.K. and Bera, M. (2003) Watershed-Scale Hydrologic and Nonpoint-Source Pollution Models: Review of Mathematical Bases. Transactions of the ASAE, 46, 1553-1566. https://doi.org/10.13031/2013.15644

[17] Gassman, P.W., Reyes, M.R., Green, C.H. and Arnold, J.G. (2007) The Soil and Water Assessment Tool: Historical Development, Applications, and Future Research Directions. Transactions of the ASABE, 50, 1211-1250.

[18] Arnold, J.G., Srinivasan, R., Muttiah, R.S. and Williams, J.R. (1998) Large Area Hydrologic Modeling and Assessment Part I: Model Development. Journal of the American Water Resources Association, 34, 73-89.

[19] Neitsch, S.L., Arnold, J.G., Kiniry, J.R. and Williams, J.R. (2001) Soil and Water Assessment Tool Theoretical Documentation Version 2000: Draft-April 2001. Grassland, Soil and Water Research Laboratory, Temple.

[20] Williams, J.R. (1975) Sediment Routing for Agricultural Watersheds. Journal of the American Water Resources Association, 11, 965-974. https://doi.org/10.1111/j.1752-1688.1975.tb01817.x

[21] Green, C. and Vangriensven, A. (2008) Autocalibration in Hydrologic Modeling: Using SWAT2005 in Small-Scale Watersheds. Environmental Modelling \& Software, 23, 422-434. https://doi.org/10.1016/j.envsoft.2007.06.002

[22] Neitsch, S.L., Arnold, J.G., Kiniry, J.R., Williams, J.R. and King, K.W. (2002) Soil and Water Assessment Tool: Theoretical Documentation, Version 2000. TWRI Re- 
port TR-191. Water Resources Institute, College Station.

[23] Van Breemen, N., Boyer, E.W., Goodale, C.L., Jaworski, N.A., Paustian, K., Seitzinger, S., Lajtha, L.K., Mayer, B., Van Dam, D., Howarth, R.W., Nadelhoffer, K.J., Eve, M. and Billen, G. (2002) Where Did All the Nitrogen Go? Fate of Nitrogen Inputs to Large Watersheds in the Northeastern USA. Biogeochemistry, 57/58, 267-293. https://doi.org/10.1023/A:1015775225913

[24] Nam, Y., An, S. and Park, J. (2011) Nitrogen Budget of South Korea in 2008: Evaluation of Non-Point Source Pollution and N2O Emission. Journal of Korean Society of Environmental Engineers, 33, 103-112.

[25] Parfitt, R.L., Schipper, L.A., Baisden, W.T. and Elliott, A.H. (2006) Nitrogen Inputs and Outputs for New Zealand in 2001 at National and Regional Scales. Biogeochemistry, 80, 71-88. https://doi.org/10.1007/s10533-006-0002-y

[26] Park, J.Y., Park, M.J., Ahn, S.R., Park, G.A., Yi, J.E., Kim, G.S., Srinivasan, R. and Kim, S.J. (2011) Assessment of Future Climate Change Impacts on Water Quantity and Quality for a Mountainous Dam Watershed Using SWAT. Transactions of the $A S A B E$, 54, 1725-1737.

[27] Nash, J.E. and Sutcliffe, J.V. (1970) River Flow Forecasting Through Conceptual Models Part I-A Discussion of Principles. Journal of Hydrology, 10, 282-290. https://doi.org/10.1016/0022-1694(70)90255-6

Submit or recommend next manuscript to SCIRP and we will provide best service for you:

Accepting pre-submission inquiries through Email, Facebook, LinkedIn, Twitter, etc. A wide selection of journals (inclusive of 9 subjects, more than 200 journals) Providing 24-hour high-quality service User-friendly online submission system Fair and swift peer-review system Efficient typesetting and proofreading procedure Display of the result of downloads and visits, as well as the number of cited articles Maximum dissemination of your research work

Submit your manuscript at: http://papersubmission.scirp.org/ Or contact as@scirp.org 